\title{
Memaksimalkan Kemampuan Guru dalam Menganalisis SK-KD melalui Diskusi
}

\author{
SUHAIMI \\ Guru SMP N 2 Gunung Sahilan \\ Dinas Pendidikan dan Kebudayaan Kabupaten Kampar
}

\begin{abstract}
The ability of teachers in analyzing SK-SD a separate issue in school, the study was conducted in SMP N 2 Mount Sahilan, based on the phenomenon of still optimal capability of teachers in preparing SK-SD. This study uses the discussion in order to improve the ability of teachers to analyze SK-SD. This type of research is action research school with the results showed that the teacher gives a positive response to the draft action research compiled by the supervisor to improve the ability of teachers to prepare lesson plans, especially in the analysis / assessment tehadap Competency Standards and Basic Competence in order to develop the syllabus. The guidance that supervisors as research followed by teachers in earnest.
\end{abstract}

Keywords: Capability Teachers, Discussions

The ability of teachers in analyzing SK-SD a separate issue in school, the study was conducted in SMP N 2 Mount Sahilan, based on the phenomenon of still optimal capability of teachers in preparing SK-SD. This study uses the discussion in order to improve the ability of teachers to analyze SK-SD. This type of research is action research school with the results showed that the teacher gives a positive response to the draft action research compiled by the supervisor to improve the ability of teachers to prepare lesson plans, especially in the analysis / assessment tehadap Competency Standards and Basic Competence in order to develop the syllabus. The guidance that supervisors as research followed by teachers in earnest.

Keywords: Capability Teachers, Discussions Berdasarkan Peraturan Menteri Pendidikan Nasional Republik Indonessia Nomor 16 Tahun 2007 tentang Standar Kualifikasi Akademik dan Kompetensi Guru, dijelaskan bahwa Standar Kompetensi Guru dikembangkan secara utuh dari 4 (empat) kompetensi utama, yaitu :(1) kompetensi pedagogik, (2) kepribadian, (3) sosial, dan (4) profesional. Pada Lampiran Peraturan Mendiknas nomor 16 Tahun 2007 tersebut, khususnya pada kompetensi Pedagogik di jelaskan bahwa guru harus mampu mengembangkan kurikulum yang terkait dengan bidang pengembangan yang diampu. Demikian dengan guru Ilmu Pengetahuan Sosial harus mampu mengembangkan kurikulum di SMP N 2 Gunung Sahilan sesuai dengan prinsip pengembangan kurikulum.

Berkaitan dengan pengembangan kurikulum, di sekolah harus dapat mengembangkan silabus dan perangkat pembelajaraan lainnya.Idealnya seorang guru Ilmu Pengetahuan Sosial dalam rangka pengembangan sialbus harus melakukan analisis standar isi dan lampiran standar isi tentang Standr Kompetensi (SK) dan Kompetensi Dasar (KD) pada mata pelajaran IPS. Guru harus memahami pentingnya melakukaan analisis tersebut dalam kaitannya dalam penyusunan silabus dan perangkat pembelajaran lainnya. Proses pengkajian dimaksud sangat penting dan bermanfaat untuk merumuskan : indikator pencapaian, materi pokok, kegiatan pembelajaran, metode pembelajaran, penentuan bentuk dan jenis soal, serta sumber/bahan belajar.

Berdasarkan pengamatan terhadap perencanaan pembelajaran yang disusun oleh guru Ilmu Pengetahuan Sosial SNIP Negeri 2 Gunung Sahilan ditemukan indikasi bahwa pada umumnya belum melakukan analisis standar isi dan lampiran standar isi tentang $\mathrm{SK}$ dan KD mata 
pelajaran Ilmu Pengetahuan Sosial.Hal ini disebabkan para guru Ilmu Pengetahuan Sosial belum memahami pentingnya dan keterkaitan hasil analisis dengan penyusunan silabus dan perangkat pembelajaran lainnya.

$$
\text { Pada umumnya dalam }
$$

mengembangkan silabus guru hanya mengutip SK dan KD pada Lampiran Standar Isi (belum melakukan pengkajian/pemetaan kompetensi), karena mereka belum pernah memahami bahwa proses pengkajian dimaksud sangat penting dan bermanfaat untuk merumuskan: indikator pencapaian, materi pokok, kegiatan pembelajaran, metode pembelajaran, penentuan bentuk dan jenis soal, serta sumber/bahan belajar. Belum semua guru memahami tata caraanalisis standar isi clan lampirannya yaitu SK dan KD.

Akibat dari ketidaktahuan tersebut, guru hanya mengadopsi clan mengadaptasi contoh silabus yang dikembangkan oleh BSNP clan sekolah lainnya.Artinya guru belum mengembangkan silabus secara mandiri sesuai dengan karakteristik siswa karena guru baru dikatakan mengembangkan silabus secara mendiri ditandai dengan melakukan pemetaan/analisis standar isi (SK dan KD) mata pelajaran yang diampunya.

Sesuai dengan permasalahan yang terjadi, maka diperlukan bimbingan kepada guru dalam melakukan pengkajian standar isi dan lampirannya ( $\mathrm{SK}$ dan $\mathrm{KD}$ ) yang akan bermanfaat dalam pengembangan silabus dengan balk yakni dalam merumuskan: indikator pencapaian KD, materi pokok, kegiatan pembelajaran, metode pembelajaran, penentuan bentuk dan jenis soal, serta sumber/bahan belajar.

Sebagai Kepala Sekolah pada SMPN 2 Gunung Sahilan, penulis berkewajiban melakukan tindakan perbaikan terhadap kemampuan guru Ilmu Pengetahuan Sosial dalam melakukan analisis standar isi dan lampirannya dalam rangka menyusun rencana pembelajaran dengan baik.Hal ini sesuai dengan tugas pokok dan fungsi sebagai Kepala Sekolah dalam supervisi akademik yakni pembinaan terhadap guru dalam merencanakan pembelajaran. Untuk itulah penelitian ini dilakukan sebagai upaya memaksimalkan kemampuan guru dalam menganalisis SK dan KD melalui diskusi dalam rangkaian supervisi akademik.

Dalam artikel ini dibahas juga mengenai acuan teori telah dikemukakan terlebih dahulu bahwa Standar Kompetensi Guru dikembangkan secara utuh dari empat kompetensi utama, yaitu: kompetensi pedagogik, kepribadian, sosial, dan profesional (Mendiknas nomor 16 Tahun 2007). Pada kompetensi Pedagogik dijelaskan bahwa guru harus mampu mengembangkan kurikulum yang terkait dengan bidang pengembangan yang diampu.Hal ini berarti bahwa guru harus memiliki kompetensi yang memadai dalam mengembangkan kurikulum yakni menjabarkan SK dan KD yang tertuang dalam standar isi ke dalam indikator-indikator pembelajaran.

Kompetensi berarti sebagai gambaraan tentang apa yang harus diketahui atau dilakukan seseorang agar dapat melaksanakan pekerjaan dengan baik. Pengertian kompetensi jenis ini dikenal dengan nama kompetensi jenis teknis atau fungsional. Kosentrasi kompetensi teknis adalah pada pekeijaan, yaitu untuk menggambarkan tanggung jawab, tantangan, clan sasaran kerja yang harus dilakukan atau dicapai oleh si pemangku jabatan agar dapat berprestasi dengan baik.(Miller, Rankin dan Neathey dalam Hutapea clan Thoha (2008:3)

Sebagai tambahan mengenai kompetensi dikemukakan oleh Wibowo (2008:86) adalah suatu kemampuan untuk melaksanakan atau melakukan suatu pekerjaan atau tugas yang dilandasi atas keterampilan dan pengetahuan serta didukung oleh sikap kerja yang dituntut oleh pekerjaan tersebut. Dengan demikian kompetensi menunjukan keterampilan atau pengetahuan yang dirincikan oleh profesionalisme dalama suatu bidang tertentu sebagai sesuatu yang terpenting, sebagai unggulan bidang tersebut.

Bila dikaitkan dengan pekerjaan guru dalam mengembangkan kurikulum (STSP), bearti kompetensi merupakan kapasitas yang 
ada pada seorang guru untuk memenuhi apa yang disyaratkan oleh pekerjaan guru sehingga mampu mencapai hasil yang diharapkan dalam pembelajaran. Oleh karena itu, guru harus mampu mandiri, karena pada hakikatnya kurikulum (KTSP) adalah sebuah model pengembangan kurikulum berbasis sekolah yang menuntut kemandirian guru (Mulyasa,2008:5). Kemandirian ini diperlukan terutama dalam mengembangkan pembelajaran dalam rangka membentuk kompetensi peserta didik dengan caramemberi makna dan merespon ilmu pengetahuan serta menjalani hubungan yang saling menguntungkan dengan masyarakat dan lingkungan.

Kurikulum yang dikembangkan oleh guru harus dirancang dengan baik yang menekankan pada isi kurikulum dan diarahkan pada penguasaan kompetensi. Sehubungan dengan hal tersebut perlu dilakukan bedah kurikulum agar dapat dirumuskan kembali standar kompetensi dan kompetensi dasar yang diperlukan dengan cara menetapkan hasil belajar dan indikator pengukuran hasil belajar (Sagala, 2010:49). Bedah kurikulum dilakukan untuk mengetahui suatu peta kurikulum baik untuk satu semester maupun untuk satu tahun.

Sehubungan dengan bedah kurikulum, terlebih dahulu guru harus mengetahui tujuantujuan dari mata pelajaran yang diampu ,mengetahui ruang lingkup mata pelajaran tersebut, dan memahami seluruh standar kompetensi dan kompetensi dasar yang terdapat dalam lampiran standar isi (Pemendiknas 22 tahun 2006). Menurut Sagala (2010:49-50) langkah-langkah dalam bedah kurikulum dilakukan dengan cara : 1). Amati scankurikulum untuk satu semester dan setahun pada mata pelajaran yang menjadi tanggung jawab guru; 2). Beberapa kompetensi mungkin saja mudah untuk dimasukkan ke dalam materi pelajaran. Tetapi mengkin saja beberapa kompetensi lain tidak cocok. Jika tidak cocok jangan memaksakan untuk memasukkannya ke dalam materi pelajaran, tetapi tempatkan kompetensikompetensi kunci/utama pada bagian sesuai dalam scan kurikulum; 3). Sebagai usaha penyesuaian materi dengan kompetensi dan indikator, maka guru malakukan reviu pada scan kurikulum. Baca baik-baik materi pelajaran dan kompetensi-kompetensi yang sudah disiapkan; 4). Apakah anda mempunyai materi pelajaran terlalu banyak atau terlalu sedikit?; 5). Apakah anda perlu mengatur kembali atau hanya menambahkan hal-hal penting saja?; 6). Apakah anda puas dengan hasilnya, dan seterusnya. Setelah dilakukan bedah kurikulum maka guru menyusun perencanaan pembelajaran.

Sebelum melaksanakan pembelajaran, terlebih dahulu guru harus mempersiapkan perencanaan pembelajaran tersebut.Perencanaan pembelajaran adalah pekerjaan yang dilakukan oleh guru untuk merumuskan tujuan pembelajaran. Dikemukakan oleh Dick dan Reister yang dikutip oleh Syafruddin dan Nasution (2005:94) sebagai berikut: "An instructional plan consist of a number of component that, when integrated, provided you with an outline for delivering effective instruction to learners. " Dipahami bahwa rencana pembelajaran terdiri dari sejumlah komponen yang jika dipadukan memberikan garis besar atau panduan bagi penyampaian pengajaran yang efektif kepada para pembelajar.

Dijelaskan dalam PP. 19 tahun 2005 bahwa pasal 20 bahwa perencanaan proses pembelajaran meliputi silabus dan rencana pelaksanaan pembelajaran yang memuat sekurang-kurangnya tujuan pembelajaraan, materi ajar, metode pengajaraan, sumber belajar, dan penilaian hasil belajar. Selanjutnya Permendiknas 41 Tahun 2007 menegaskan bahwa perencanaan proses pembelajaran meliputi silabus dan rencana pelaksanaan pembelajaran (RPP) yang mernuat identitas mata pelajaaran, standar kompetensi (SK), kompetensi dasar (KD), indikator pencapaian kompetensi, tujuan pembelajaran, materi ajar, alokasi waktu metode pembelajaran, kegiatan pembelaajaran, penilaian hasil balajar, dan sumber belajar. 
Berdasarkan Panduaan Penyusunan KTSP yang dikeluarkan oleh Badan Standar Nasional Pendidikan (2006:12) dijelaskan bahwa rencana pembelajaran dituangkan dalam bentuk silabus.Silabus adalah rencana pembelajaran padaa suatu dan/atau kelompok mata pelajaran/tema tertentu yang mencakup standar kompetensi, kompetensi dasar, penilaian, alokasi waktu, dan sumber belajar. Salim (1987: 98) mengemukakan bahwa silabus dapat didefinisikan sebagai "Garis besar, ringkasan, ikhtisar, atau pokok-pokok isi atau materi pelajaran".Istilah silabus digunakan untuk menyebut suatu produk pengembangan kurikulum berupa penjabaran lebih dari SK dan KD yang ingin dicapai, dan materi pokok serta uraian materi yang perlu di pelajari peserta didik dalam rangka mencapai SK dan KD.

Dalam rangkaian perencanaan pembelajaran yakni pengembangan silabus, guru terlebih dahulu harus melakukan analisis/pengkajian terhadap standar kompetensi dan kompetensi dasar mata pelajaran sebagaimana tercantum pada Standar Isi.Analisis/pemetaan SK-KD sangat bermanfaat dalam rangkaian pengembangan Silabus. Kompetensi adalah merupakan gabungan keterampilan, perilaku, dan pengetahuan yang dapat didemontasikan oleh pelajar setelah mereka belajar (Sagala,2010:42). Dijelaskan dalam Permendiknas nomor 22 Tahun 2006 bahwa Standar Kompetensi merupakan ukuran kemampuan minimal yang mencakup pengetahuan, keterampilan dan sikap yang harus dicapai, diketahui, dan mahir dilakukan oleh peserta didik pada setiap tingkatan dan suatu materi yang diajarkan. Sedangkan Kompetensi Dasar merupakan penjabaran SK peserta diidk yang cakupan materinya lebih sempit disbanding dengan SK peserta didik.

\section{METODE}

Peneliti melaksanakan Penelitian Tindakan Sekolah (PTS) ini bertempat di Sekolah Menengah Pertama (SMP) Negeri 2 Gunung Sahilan yang terletak di Desa Kebun Durian Kecamatan Gunung Sahilan Kabupaten.
Kampar Provinsi Riau. Sebagai subjek tindakan dalam penelitian ini adalah guru mata pelajaran Ilmu Pengetahuan Sosial yang berjumlah 5 (lima) orang dengan objek tindakan adalah kemampuan guru Ilmu Pengetahuan Sosial dalam menganalisis SKKD dalam mengembangkan silabus. Analisis data dengan menggunakan jenis penelitian tindakan kelas.

\section{HASIL}

Sebagamana telah dijelaskan terdahulu bahwa tempat penelitian tindakan ini dilaksanakan adalah pada Sekolah Menengah Pertama (SMP) Negeri 2 Ginning Sahilan yang merupakan sekolah tempat bertugas penelitian terletak di Desa Kebun Durian Kecamataan Gunung Sahilan Kabupaten Kampar Provinsi Riau. Sekolah ini merupakan sekolah rintisan kategori (SSN) yang memiliki rombongan belajar sebanyak 3 rombel dengan jumlah siswa laki-laki dan prempuasn.Kelas VII sebanyak 3 (rombel) kelas, kelas VIII sebanyak 3 (rombel) kelass dan kelas IX sebanyak 3 (romel) kelas Waktu belajar dilaksanakan pagi hari.

Tenaga pendidik (guru) berjumlah 18 orang yang terdiri dari guru PNS 6 orang. Guru sejarah berjumlah 4 (empat) orang. Namun sebagai subjek penelitian ini berjumlah 4 (empat) orang guru. Hat ini disebabkan kesulitan untuk mengattur jadwal pelaksanaan tindakan.Maka diputuskan guru yang lain akan dilakukan tindakan dengan materi yang berbeda. Agar tidak mengganggu proses belajar mengajar, proses penelitian tindakan ditetapkan pada hari Sabtu, karena pada hari itu gurur subjek penelitian tidak ada jam mengajar.

Penelitian tindakan ini dilaksanakan dalam dua siklus.Siklus I dilaksanakan dalam tiga kali pertemuan yakni pertemuan pertama dilaksanakan pada tanggal 11 Mei 2015 pertemuan kedua dilaksanakan pada tanggal 18 Mei 2015 dan pertemuan ketiga dilaksanakan pada tanggal 25 Mei 2015. Sementara itu siklus II dilaksanakan dalam dua kali pertemuan yakni 
pertemuan pertama dilaksanakan pada tanggaal 01 Juni 2015 pertemuan kedua dilaksanakan pada tanggal 15 Juni 2015.

Mei 2015 diawali dengan meinberikan penjelasan tetang tata cara kegiatan-kegiatan yang akan dilakukan dalam pelaksanaan penelitian tindakan. Peneliti menanyakan apakah guru-guru memahami tujuan kegiatan yang akan dilakukan dan menyetujui tentang tata cara serta waktu pelaksanaan kegiatan tersebut. Setelah disepakati bersama antara guru dengen peneliti kegiatan-kegiatan yang akan dilakukan, selanjutnya peneliti mempersentasikan materi secara garis besar tentang cara-cara menganalisis/mengkaji SKKD dalam rangka menyuusn silabus/rencana pembelajaaran yang sebelum belum dilakukan oleh guru. Selesai pelaksanaan presentasi oleh peneliti, dilakukan diskusi dengan guru-guru tentang materi yang dipaparkan.

Selama kegiatan diskusi berlangsung, peneliti melakukan pengamatan dengan menggunakan format yang telah disediakan.Aspek yang diamati antara kesungguhan guru untuk mengikuti kegiatan yang terdiri dari dua komponen yakni kehadiran mengikuti kegiatan dan keaktifan dalam diskusi. Peneliti melakukan analisis terhadap pelaksanaan kegiatan.Berdasarkan hasil analisis ini peneliti melakukan refleksi untuk menentukan keberhasilan penelitian tindakan dan merencanakan tindakan berikutnyaa.

Telah dijelaskan terdahulu bahwa penelitian tindakan sekolah ini dilaksanakan dalam dua siklus.Begaimana pelaksanaan persiklus dapat dideskripsikan sebagai berikut: Siklus I

Berdasarkan hasil pertemuan awal dengan guru-guru, semuanya memberikan tanggapan yang positif terhadap rencana tindakan yang akandilakukan peneliti. Pada umumnya mereka antusias untuk mengetahui bagaimana melakukan penelitian tindakan.Diperoleh juga informasi bahwa mereka ingin sekali untuk melakukan penelitian tindakan kelas dan mendapat bimbingan dari pengawas sekolah. Selain itu materi yang akan dibahas dalampenelitian tindakan juga akan memberikan pengalaman barn bagi guru-guru. Mereka mengakui bahwa melakukan pemetaan/analisis SK-KD merupakan hal yang sulit dilakukan guru.

Telah dijelaskan terdahulu bahwa guru yang mengikuti kegiatan sebanyak 5 (lima) orang guru Bahasa Indonesia. untuk melihat kesungguhan guru dalam mengikuti kegiatan. Pemahamam Guru Terhadap caracara mengkaji/menganalisis SK-KD Pemehaman guru terhadap cara mengkaji/menganalisis SK-KD dalam rangkaian penyusunan silabus yang diperoleh dari hasil presentasi. Data yang diperoleh sebagai hasil pengamatan dari diskusi dan presentasi dalam mengkaji/menganalisis SKKD Siklus I dalam tangkaian pengembangan silabus.prencanaan pembelajaran dengan tujuh indikatornya kemudian dianalisis. Berdasarkan analisis ini, diperoleh beberapa temuan yang kemudian dijadikan refleksi, yakni: a) Pada umumya guru-guru memberikan tanggapan positif terhadap penelitian tindakan yang dilakukan oleh pengawas. Demikian juga dengan langkah-langkah kegiatan yang disusun secara keseluruhan dapat disetujui oleh guru. b) Kesungguhan guru-guru dalam mengikuti kegiatan cukup bagus, hanya satu orang yang terlambat pada pertemuan pertama, sedangkan yang tidak hadir tidak ada. Keaktifan dalam diskusi pada pertemuan pertama siklus I berjalan tidak seimbang.Guru-guru terlihat masih enggan atau malu untuk bertanya kepada pengawas. Sehingga kegiatan didominasi dua orang dari lima orang guru. Setelah mendapat pengarahan dan motivasi dari pengawas berulah terjadi perubahan suasana.Pengawas mengarahkan agar guru $\mathrm{j}$ angan malu bertanya kepada pengawas atau teman halhal yang belum dipahami.Pada pertemuan kedua dan ketiga terjadi peningkatan yang berarti. Guru tidak lagi malu atau enggan untuk bertanya kepada pengawas. Demikian juga dalam memberikan komentar terhadap presentasi hasil analisis dan menjawan pertanyaan yang diajukan oleh teman. c) Dan hasil pengamatan terhadap analisis/pengkejian SK-KD yang dilakukan guru dalam rangka menyusun rencana pembelajaran ternyata 
belum dapat sepenuhnya dikuasai oleh guru. Hal ini dapat dilihat pada table 4.2 diatas. Baru satu orang guru yang sudah menguasai sepenuhnya indikator yang diberikan yakni sebesar 100\%.Diperoleh informasi bahwa guru yang bersangkutan pernah mengikuti pelatihan. Sedangkan dua orang hampir menguasal, hanya penentuan THB indikator KD yang masih kesulitan, penguasaannya sebesar $57 \%$ dikarenakan belum pernah mendapatkan pelatihan

Hasil refleksi siklus I dapat dikatakan belum memenuhi kriteria keberhasilan yang telah ditetapkan dalam penelitian ini.Untuk itu penelitian ini dilanjutka pada siklus II.

\section{Siklus II}

Untuk siklus II dalam penelitian tindakan ini dirancang berdasarkan hasil refleksi dari siklus I, sehingga masingmasing siklus saling berkaitan. Dengankata lain bahwa siklus II merupakan modifikasi dari siklus I. hal ini dimaksudkan untuk mendapatkan hasil yang lebih baik, sehingga indikator yang ditetapkan dapat tercapai. Siklus II mi juga dilaksanakan dalam dua kali pertemuan.

Berdasarkan hasil pertemuan awal pada siklus II dengan guru-guru, semuanya masih memberikan tanggapan yang positif terhadap rancangan tindakan penelitian yang akan dilanjutkan.

Beberapa temuan yang kemudian dijadika refeleksi, yakni: a) Langkahlangkah kegiatan tindakan lanjut yang disusun oleh peneliti secara keseluruhan dapat disetujui oleh. b) Guru semakin antusias dalam mengikuti kegiatan, tidak ada lagi yang terlambat dan yang tidak hadir dalam mengikuti kegiatan. Keaktifan dalam diskusi pada pertemuan pertama siklus II sudah berjalan dengan baik.Guruguru tidak lagi enggan atau malu untuk bertanya kepada pengawas sehingga kegiatan tidak lagi didominasi oleh guru tertentu. c) Dari hasil pengamatan terhadap analisis/pengkajian SK-KD yang dilakuakan guru pertemuan kedua siklus II pada umumnya indokatorindikator yang dijadikan ukuran, hamper seluruhnya dapat dipahami oleh guru. Walupun masih ada satu indikator yakni: "Penentuan THB KD" dan "Perumusan Indikator KD" belum dikuasasi oleh dua orang guru, namaun secara umum guru telah dapat melakukan cara-cara menganalisis/ pangkajian SK-KD dalam rangka pengembangan silabus/ rencana pembelajaran.

Hasil refleksi pertemuan kedua siklus II dapat dikatakan telah memenuhi kriteria keberhasilan yang telah ditetapkan dalam penelitian ini.Untuk itu peneliti ini tidak perlu dilanjutkan pada pertemuan atau siklus berikutnya. Dengan kata lain tujuan yang ingin dicapai dalam penelitian tindakan ini telah dapat dicapai.

\section{PEMBAHASAN}

Cara pembinaan yang dilakukan oleh peneliti/pengawas dalam membimbing guru, khususnya cara-cara melakukan analisis/pengkajian SK-KD cukup disenangi oleh guru.Pada umumnya guru menyukai clan termotivasi untuk mengikuti pembinaan yang dilakukan oleh pengawas.Secara aklamasi guru menyetujui rancangan penelitian tindakan yang dilakukan oleh pengawas/peneliti. Pengakuan jujur yang disampaikan oleh guru bahwa selama ini mereka kurag memperhatikan hal-hal yang berkaitan analisis SK-KD.Para guru hanya mengadopsi silabus yang dikembangkan oleh BSNP tanpa melakukan analisis. Bahkan ditemukan guru yang tidak pernah melihat lampiran Peraturan Menteri Pendidikan Nasional nomor 22 Tahun 2006 tentang Standar Kompetensi dan Kompetensi Dasar. Artinya guru belum melakukan perencanaan pembelajara dengan baik.Hal ini tentu saja akan berdampak pada hasil belajar siswa. Guru diharapkan mampu membuat perencanaan secara balk agar guru memiliki kemampuan menyampaikan pengajaran, karena perencanaan itu akan member kemudahan siswa dalam mengerahui dan memahami materi pelajaran. (Johnson dalam Muchith, 2008:102). 
Para peserta bimbingan mengungkapkan sebagai berikut :"bimbingan yang dilakukan pengawas/penelitis sangat bagus dan dapat menambah wawasan kami. Jarang sekali kami mendapat bimbingan seperti yang dilakukan peneliti sekarang mi. Kami puas dan sangat terbantu karena dapat bertanyaa langsung kepada pengawas dan dapat bekerja sama dengan teman sejawat dalam merencanakan pembelajaran. Kami mengharapkan agar bimbingan seperti ini dapat dilanjutkan dengan materi lain seperti penilaian"

Ungkapan guru yang disampaikan tersebut menunjukan bahwa mareka sangat menyenangi pembinaan oleh pengawas yang dilakukan secara kontinu. Artinya bimbingan yang dlakukan oleh pengawas sangat dibutuhkan oleh guru karena mereka merasa terbantu dalam melaksanakan tugas proses belajar mengajar khususnya dalam merencana kan pembelajaran. Mengingat bertanya tugas guru terutama dalam merencanakan pembelajaran, sudah sehatusnya diberikan bantuan agar para guru memahami bagimana suatu konsep, pokok bahasan dan suatu tema disusun, direncanakaan dalam kegiataan belajar agar para siswa memperoleh berbagai pengalaman belajar.Hal ini sesuai dengan fungsi supervisi yakni membantu para guru agar bisa dan dapat bekerja secara professional sesuai dengan kondisi masyarakat tempat sekolah itu berad. (Made Pidarta, 2009:4)

Dilihat dari kesungguhan guru dalam mengikuti kegiatan bimbingan yang dilakukan oleh peneliti/pengawas cukup mengembirakan.Tidak ada guru yang absen mengikuti tahapan-tahapan kegiatan yang dilakukan.Partisipasi pada peserta bimbingan dalam pelaksanaan kegiatan terutama diskussi cukup mengembirakan.Bimbingan dan pemberian mitivasi yang dilakukan oleh pengawas/peneliti dapat membantu clan menumbuhkan rasa parcaya diri para guru untuk menyelesaikan persoalan-persoalan dalam penbelajaran.Seperti dikemukakan oleh Hamalik (1992:169) bahwa seorang supervisor berekewajiaban untuk membina, mengarahkan serta member bimbinnan agar guru dapat meningkatkan profesinya serta kemampuan kinerjanya.

Manfaat lain yang dirasakan oleh peserta bimbingan dalam pembinaan yang dilakukan pengawas/peneliti yakni dapatnya dikembangkan kemampuan kerja sama guru dalam mengatassi kesulitankessulitan dalam pembelajaran, khususnya materi yang dibahas. Diskusi dan kerjasama dalam merancang pembelajaran jarang dilakukan oleh guru, sehingga menyulitkan mereka dalam mengembangkan materi ajar dalam pembelajaran dengan teman sejawat, kepada sekolah agar dan staf lainnya (Bafadal, 2003:89). Artinya mereka harus menjadi tim yang solit dalam mencapai tujuan pembelajaran.

Dalam kegiatan belajar-mengajar di kelas, diperlukan adanya usahausaha yang optimal agar kegiatan belajar tersebut membuahkan hasil yang diharapkan. Pada konteks ini, guru sebagai fasilitator harus berperan memberikan pelayanan untuk memudahkan siswa dalam kegiatan proses pembelajaran tersebut. Melalui bimbingan yang diberikan oleh pengawas guru merasa terbantu dan termotivasi untuk mengikuti kegiatan, sehingga mereka bersungguhsungguh dalam mengikuti kegiatan yang dilakukan oleh pengawas. Sebagaimana dikemukakan oleh Suhertina (2000:141) bahwa guru perlu mendapatkan sport dan bantuan dari supervisor (pengawas) dalam melaksanakan proses belajar-mengajar. Artinya melalui arahan dan motivasi (tindakan) yang diberikan pengawas dalam penelirian tindakan ini telah dapar membantu guru dalam meningkatkan kemampuannya melaksanakan tugas proses belajar-mengajar 
sehingga mereka bersungguhsungguh dalam mengikuti kegiatan.

Pemahaman Guru Terhadap Cara-cara Menbanalisis/Pemetaan SK-KD, sebagai mana telah dijelaskan di atas bahwa ada tujuh aspek yang diukur dalam dari kegiatan melakukan analisis/pemetaan SK-KD dalam merencanakan pembelajaran.Ketujuh indikator tersebut hampir semuanya dapat dilakukan guru dengan baik. Artinya melalui observasi presentasi dan dilanjutkan dengan diskusi serta arahan yang dilakukan melalui penelitian tindakan ini telah dapat meningkatkan kemampuan guru untuk melakukan analisis/pemetaan SK-KD dalan merencanakan pembelajara. Dari hasil kegiatan penelitian tindakan yang dilakukan telah memperlihatkan bahwa bimbingan yang dilakukan secara sistematis tersebut mempunyai dampak yang sangat besar terhadap peningkatan kemampuan guru daam merencanakan pembelajaran. Dengan demikian dapat dikatakan bahwa guru dalam melaksanakan tugas proses belajarmengajar memerlukan pembinaan secara kontinu dan sistematis. Pembinaan secara kontinu dan sistematis sebagaimana yang dilakukan dalam penelitian persoalanpersoalan dalam pembelajaran. Supervisor.pengawas harus dapat membina guru yang siap menempah sumber daya manusia yang berbeda pengetahuan danaketerampilannya. (Made Pidartaa, 2008:85).

\section{SIMPULAN}

Guru memberikan respon positif terhadap rancangan penelitian tindakan yang disusun oleh pengawas untuk meningkatkan kemampuan guru dalam menyusun perencanaan pembelajaran khususnya dalam melakukan analisis/ pengkajian tehadap Standar Kompetensi dan Kompetensi Dasar dalam rangka pengembangan silabus. Pembinaan yang dilakukan pengawas sebagai penelitian diikuti oleh guru dengan sungguh- sungguh. Kesungguhan ini ditandai dari kehadiran dalam mengikuti kegiatan pembinaan dan partisipasi aktif mereka dalam mengikuti diskusi yang dilakukan. Guru dapat memahami cara-cara yang dilakukan dalam menganalisis/ mengkaji standar kompetensi (SK) dan kompetensi dasar (KD) melalui bimbingan dan arahan, yang diberikan oleh pengawas yang dilakukan dalam penelitian tindakan ini. Melalui arahan yang diberikan oleh pengawas dan diskusi dan serta presentasi yang dilakukan dalam penelitiaan tindakan ini, guru telah dapat menerapkan analisis/pengkajian SK-KD dalam rangka pengembangan silabus/ perencanaan pembelajaran.

\section{DAFTAR RUJUKAN}

Bafadal, Ibrahim, 2003, Peningkatan Profesionalisme Guru Sekolah Dasar, Jakarta: Bumi Aksara

Depdiknas, 2007, KTI Laporan Hasil Penelitian, Direktorat Tendik Direktorat Jendral PMPTK.

Hamalik, Oemar, 1992, Administrasi Supervisi Pengembangan Kurikulum, Bandung: Mandar Maju.

Hutapea, Parulian dan Nuriana Thoha, (2008) Kompetensi Plus, Teori, Desain, Kasus Dan Penerapan Untuk HR Dan Organisasi Yang Dinamis, Jakarta : Gramedia Pustaka Umum.

Muchith, Seakhan, (2008), Pembelajaran Kontekstual, Semarang raSAILMedia Group.

Mulyasa, H.E. (2008), Implementasi Kurikulum Tingkat Satuan Pendidikan, Kemandirian Guru Dan Kepala Sekolah, Jakarta : BumiAksara. 
Pidarta, Made, (2009), Manajemen Pendidikan Indonesia, Jakarta : Rineka Cipta

Sagala, Syaiful, (2010) Supervise Pembelajaran Dalam Profesi Pendidikan, Bandung : Alfabeta,

Salim, Peter, (1987). The Contemporary English Indonesian Dicrionary. Jakarta : Modern English Press

Suherian, Puet, 2000, Konsep Dasar \& Teknik Supervisi Pendidikan, Jakarta: Rineka Cipta.

Syafruddin, Irwan Nasution, 2005, Manajemen Pembelajaran, Jakarta: Quantum Teaching.

Wibowo, (2008), Manajemen Kinerja, Jakarta : Raja Grafindo Persada. 